prises four rooms, each 20 feet long, 16 feet wide, and 14 feet high. In the entrance hall is placed the telegraphic apparatus; to the right is my private office, where the library is placed, contained in glazed teak-wood bookcases, to protect the books from insects in the summer. I have already received extensive donations from scientific institutions in all parts of the world. The room next to this contains the clocks, which are fixed to brick piers neatly covered with teak wood. The piers, which rest on cement concrete, are carried down 6 feet below the ground in holes lined with bricks. Behind this is a small room in which the galvanic batteries are placed.

6. The mean-time clock, which is to discharge the timeball automatically, is furnished with a magnetic apparatus for setting to correct time without touching any part of the clock. The time-ball will be dropped at Tsim-sh'at-sui Point, opposite the harbour, about a mile from the Observatory. It is 6 feet in diameter. Opposite the meantime clock is the sidereal standard clock, which is of the most finished construction. It communicates by wire with a sympathetic dial placed in the transit-room. The face of the latter is black, and the hands and the figures are white, which I found very convenient at Markree Observatory, but unfortunately, Messrs. Dent and Co., who made all the horological apparatus, have omitted a second every minute. For marking a chronograph such an arrangement is most desirable, but it is rather awkward in observing with eye and ear. The clock-room contains the relays, and also one sidereal and two meantime chronometers.

7. The transit instrument, by Troughton and Simms, is placed in a wing room painted dark gray, I4 feet square and 14 feet high, next the clock-room. The meridian opening is I foot wide. The transit instrument has also a delicate level for observing zenith distances according to Talcott's method. The pivots are made of chilled bellmetal, a material which, I believe, was introduced to astronomical instrument-makers by Brinkley of Dublin, whose instruments remain serviceable up to this dav, while the pivots of transit instruments of much later date are corroded, being made of steel-a material that should not be used except where unavoidably necessary. An adjustable meridian mark is placed on a pier 66 feet north of the transit instrument. It is observed through a lens of that focal length, which is fixed in the meridian of ening of the transit-room.

8. To the left of the entrance hall is the general office and computing room, next to which is the room where the barometers, as well as the self-recording thermograph and barograph, are placed. Behind this is a small room that serves as a photographic laboratory. Every part of these two rooms, including ceilings, floors, and furniture is painted dark red, and there are only a few panes of glass in the windows, which are glazed with double red glass. The thermograph is supported by massive blocks of wood fixed on solid masonry, but the barograph is placed on a stand merely screwed to the floor. The screw that holds the self-registering thermograph is made of zinc.

9. Over the upper story of the building a turret rises 8 feet above the flat roof. This holds the self-recording parts of the anemometer, which is erected on top of it. The cups are 45 feet above the ground. The roof forms a convenient platform for making observations. The sunshine-recorder is placed in a groove in the coping-stone on the parapet, 34 feet above the ground. Lightning conductors are placed on the two chimneys. They rise a few feet higher than the anemometer.

I0. A one-storied block of outbuildings, containing servants' quarters and store-rooms, communicates with the main building by a covered passage.

II. The magnetic hut is I 7 feet long, I 3 feet broad, and the roof rises I I feet high. It is made of wood, painted pure white outside and inside. Bamboo chips instead of nails were used in its construction, as well as in that of the furniture. It has double doors, louvered and glazed, to the north and south, and two windows on either side, as well as two windows in the roof, which is convenient for reading the verniers. $\mathrm{C} n$ top of massive teak-wood blocks sunk $3 \frac{1}{2}$ feet in the ground and rising 4 feet above the floor are placed the dip-circle and the unifilar magnetometer. All the instruments were brought out safely, except the dipping needles, which appear not to have been sufficiently cleaned before packing. The hut is very comfortable, and forms therefore, in my opinion, a contrast to other structures used for making magnetic observations, in arranging which the importance of attending to the comfort of the observer in the hut is but too often lost sight of. The deviation is only 47 minutes easterly. The dip is 32 degrees (north end dipping). A broad road leads from the main building to the magnetic hut. This road is broken in the middle by a depression, across which a bridge will shortly be built.

12. Beside this road, at a distance of about 75 feet from the main building, it is intended to build a small house for the assistants, and near this has been selected the site for the refractor of 6 inches aperture, the loan of which I was promised by the Astronomer-Royal. That will complete the outfit.

$$
\text { W. DOBERCK }
$$

Hong Kong Observatory, March in

Government Astronorner

\section{THE CEDAR FOREST OF CYPRUS}

I I 879 Sir Joseph Hooker communicated to the Linnean Society ${ }^{1}$ the unexpected discovery of a form of the cedar of Lebanon (Cedrus libani var. brevifolia, Hook. f.) by Sir Samuel Baker in Cyprus.

The following extract from a letter lately received by the Director of the Royal Gardens, Kew, from Sir Robert Biddulph, K.C.M.G., C.B., the High Commissioner, gives a more detailed account of the forest, and will no doubt be interesting to many readers of NATURE :-

$$
\text { "Cyprus, March } 25
$$

"With regard to the cedars, I went last summer all through the thickest part of the forests, including the cedar forest, and I am able to give you some of the particulars you ask for, having noted them at the time. The cedar forest occupies a ridge on the principal watershed of the southern range, and about fitteen miles west of Mount Troodos. The length of the forest is about three miles, its breadth very much less. A few outlying cedartrees were visible on neighbouring hills, but on the ridge they were quite thick, and probably many thousands in number. I took the height above the sea by an aneroid barometer, and found it to be 4300 feet. The trees are very handsome and in good condition, but comparatively young. The smallest seemed to be from ten to fifteen years old ; the largest, I am told by the principal forest officer, are probably not over sixty or seventy years. The worst feature is that there were no seedlings or joung trees under ten years; and indeed this is the same with regard to the pine forests. It would seem as if the great influx of goats has been comparatively recent. I made a tour through the heart of the forest last August. I started from a point on the west coast, and from thence ascended to the main watershed, and kept along the top till I reached Mount Troodos, taking three days to do it. The country through which we passed on the first day was perfectly uninhabited, and a mass of hills and forest, chiefly Pinus maritima $[P$. halepensis] and the Ilex. The trees were in very great number, but there was a scarcity of young trees, and most of the old ones had been tapped for resin. On the second day we passed through the cedar forest, and the same sort of country as before, the Pinus Laricio beginning at an altitude of 4000 
feet. We got as far as the monastery of Kikko that day, and the next day I continued along the watershed to the camp at Troodos. Our road as far as Kikko was a mere track on the side of the hill, in some parts rather dangerous, and we had to lead our ponies or foot, in many parts very steep. The difficulty on the road is the want of water at that elevation. We halted the first night at a beautiful spring, but we had to carry with us food for man and beast for the whole party, muleteers, \&c. The scenery was wild and romantic. This spot is the centre of the 'moufflon' ground; three of them were at the spring when we approached it. It gave me a clearer idea of the forests of Cyprus than I ever had before.

"We have bad a great deal of rain this winter, and the country is clothed with vegetation."

\section{MINERAL RESOURCES OF THE UNITED STATES ${ }^{1}$}

THIS volume, published by the United States Geological Survey, is the first statistical report upon the condition of the mining industries of the United States, and contains much valuable information concerning the great and ever-increasing production of metals, especially in the States west of the Missouri and the Rocky Mountains.

In addition to the columns of figures of weights and values constituting the statistical matter proper, the author, or rather his coadjutors, for the volume is the work of many contributors, have furnished notices and descriptions of processes, especially in the metallurgical section; and a review of the course of the markets for the preceding eight years (to 1875) is given for each important metal. By a curious provision in the Act of Congress providing for the publication of these statistics, the field is restricted to mineral products other than gold and silver, but, in order to present as complete a view of the total output as possible, the best available figures of the production of precious metals are given in a concise form. This, though valuable, is rather disappointing, as we miss the interesting accessory descriptions which are given in other parts of the volume. How important the production of these metals has been during the last quarter of a century is seen in the statement that the aggregate yield up to the middle of last year has been 2707 tons of gold and I 5,680 tons of silver, and of these enormous quantities less than I per cent. of the gold, and none of the silver was raised before 1858 At the present time the annual production varies from i2 to 16 millions sterling coinage value, divided about equally between gold and silver, the latter being usually a little in excess.

The coal raised in the different States is a little over 87 million tons, of which 29, I20,000 tons were anthracite and the remainder bituminous coal and lignite of all kinds, and $s$ me anthracite mined "outside" of Pennsylvania, the recorded value being $29,326,000$ l. The above totals represent I. 8 ton per head per annum of the population, which is, however, somewhat less than the consumption, in addition to enormous quantities of wood and charcoal. Among the most interesting recent developments are the Tertiary and Cretaceous coal-basins which extend along tive base of the Rocky Mountains and are also seen at different points on the Pacific Coast, the total area of these being reported as greater than those of the Carboniferous formations proper in the Eastern States. These areas are, however, marked as doubtful by the author. At Crested Butte and Irwin, in the very heart of the Rocky Mountains, both antbracite and good coking coals are found in these newer formations, the quality of the latter especially being comparable with the coal of Connellsville or the best coking coal in Pennsylvania.

I "Mineral Resources of the United States." By Albert Williams, jun. 8vo. (Washington, $188_{3}$.)
The iron industry of the United States is now of first-rate importance, and the subject is well treated in a paper contributed by Mr. J. M. Swank, the well-known secretary of the American Iron and Steel Association. The iron ore raised is in round numbers 9 million tons, and the pig iron made from it $4,623,000$ tons. The value of the latter is given at $21,267,000 \mathrm{l}$., which is only a few pounds less than that of the gold, silver, copper, and lead taken together. The largest production of iron ore is in the district producing the richest quality, namely Lake Superior, whose yield of $2,948,000$ tons is comparable with those of the other great hematite districts of the world, Furness, Whitehaven, and Bilbao.

The United States are now among the largest producers of copper, and here we are met by the peculiarity of the unequal distribution of the producing centres. Thus, of a total product of 40,903 tons, 25,439 tons were from a single district, namely, Lake Superior, and of this again the larger proportion, I4,309 tons, was from a single mine, the "phenomenal" Hecla and Calumet of Houghton, Michigan. The Lake copper is entirely produced from the native metal, and is of the highest degree of purity. Latterly, however, a competitor of some importance has arisen in the south, in the barren desert country of Arizona, where masses of carbonates and oxides have been discovered in considerable quantity under conditions resembling some of the famous mines of South Australia. The handling of these ores is not, however, easy. The smelting must be done on the spot, and when the furnaces are at a distance from railways, the coke used may cost from 10l. to $15 l$. per ton. The most remarkable mine in this district, the Copper Queen, has already paid 200,000l. in profits, and produces copper at a cost of $4 \frac{1}{2} d$. to $5 d$. per pound.

Lead is another metal in which the United States have taken a prominent position during the last few years, the product being now 132,890 tons, while in 1870 it was only i 7,830 tons. This great increase is due to the development of several important groups of mines in the Western States, but more particularly in Utah, Nevada, and Colorado, the latter State alone producing 58,642 tons, or nearly half the total production of the country; while in I 873 the State was credited with only 56 tons. This enormous increase is due to the development of the carbonate deposits of Leadville, in the Rocky Mountains, where ores containing only to to 20 per cent. of lead are smelted in enormous quantities to obtain the silver and gold contained, which are relatively high in proportion; the pig lead or "base bullion" produced being sent eastward by railway to the refineries at Omaha, Chicago, St. Louis, Pittsburg, and even New York. The information given in the volume concerning this important branch of industry is so full that it will be a welcome one to the library of every metallurgist.

Another important and almost specially American mineral industry is that of petroleum, the production being restricted to the States of Pennsylvania, New York, California, West Virginia, Ohio, and Kentucky, the last four being, however, insignificant as compared with the first three. Here again there is a considerable disparity, the States of Pennsylvania and New York yielding 6r,200 barrels daily, while in California the annual total is only 70,000 barrels. The barrel contains 42 gallons U.S. measure, which is the same as the old English wine gallon of 231 cubic inches. The consuming power of the world seems in this article to have been passed by the supply, the average price of $4 \mathrm{Is} .2 d$. per barrel in 1864 having fallen to $3 s$. $4 d$. in 1883 . Notwithstanding this great fall in price the total produce of the year is valued at $£ 4,740,000$, or about one-half more than that of the copper.

The minor metallic and other minerals are of Jess importance, but their statistics are set forth in considerable detail in other parts of the volume, which we hope to see 